\title{
PRACTICUM GUIDE: BASIC PHYSICS BASED OF SCIENCE PROCESS SKILL
}

Darmaji*, Astalini, Dwi Agus Kurniawan, Hanaiyah Parasdila, Irdianti, Siti Hadijah, Rahmat Perdana

Physics Education, Faculty of Teaching and Education, Universitas Jambi, Indonesia

Email: darmaji@unja.ac.id

Article History: Received on $18^{\text {th }}$ March 2019, Revised on $17^{\text {th }}$ May 2019, Published on $4^{\text {th }}$ September 2019

\begin{abstract}
Purpose: This research aims to develop basic physics practicum guidebooks based on science process skills that can assist students in training and developing students' science process skills through practicum
\end{abstract}

Design/methodology/approach: This research is development research that uses the analysis, design, development, implementation, and evaluation that adopted from Branch

Findings: Based on the validation results indicate that the reconstruction of basic physics practicum guidebooks based on science process skills that got good category result so that it can be used.

Research limitations/implications: The results of student responses when using the reconstruction of basic physics practicum guidebooks based on science process skills are well categorized so as to improve students' science process skills

Social implications: By using the reconstruction of basic physics practicum guidebooks based on science process skills of this student can have good skills so as to have experience as a prospective teacher so that later can teach it to students in science class.

Keywords: Practicum, Guidebooks, Science Process Skills, Basic Physics, Discovery Learning.

INTRODUCTION

Skill is a person's ability to use reason and thoughts, ideas and creativity smoothly in doing a job. In learning, skill consists of various one of them in science learning which is known as science process skill. The science process skills are for scientific investigation attained by students as a result of learning science (Sheeba, 2013). In essence in science learning, especially physics, a student will better understand and memory longer memory if do and find it yourself (Zeidan, 2015). However, the most important is the habituation in finding concepts made through experimental and scientific research. Practical activities bring students, dealing directly with problems related to the lecture and then given the opportunity to solve the problem (Etiubon \& Udoh, 2017). Efficient laboratory use has a significant relationship to the skills of the science process and learning achievement (Feyzioğlu, 2009). Science, as a process, students must learn skills such as observing, classifying, predicting, inferring, and hypothesizing (GBG 005, 2005). Therefore, to realize these activities need a lab in the laboratory to improve the skills of the science process.

At the National Qualifications Framework curriculum Indonesia there a level capability to be possessed by an undergraduate physics education is mastering theoretical concepts field of knowledge and skills in depth. To be able to master skills in depth can be done through a practicum with SPS approach (Science Process Skills). Science process skills (SPS) are the thinking skills of scientists to build knowledge in solving problems \& formulating results (Özgelen, 2012). Science process skills are beneficial in that students can be realized by participating in the inquiry of the science laboratory. Science process skills are inseparable in practice (Karamustafaoglu, 2011). Rezba, et al (1995) classifies the science process skills into two basic skills and integration. Classification of science process skills by Rezba in Cansiz (2015), Basic science process skills are the ones used to explore the natural world. These skills include observing, predicting, inferring, classifying, measuring, and communicating. Integrated process skills are scientific investigative skills such as identifying variables, building hypotheses, analyzing investigations, tabulating and graphing data, determining variables, designing investigations, and experimenting.

Science process skills in physical education courses the Universitas Jambi are in a low category. It is obtained based on the results of research conducted by Normayanti (2017), Kuswanto (2017) and Lestari (2017) that the overall science process skills Jambi university physics education students categorized as not good. Factors that influence is given less instructional materials science process skills training. Teaching materials play a vital role in student's academic (Effiong, et al, 2015). It is necessary for a change in teaching material that students have a good science process skills and a good pedagogic competence, we conducted a reconstruction of the guidebook based practicum science process skills. This science process skills used for later practicum student response to the better.

The use of new process-based practice guides as the reconstruction of a long-term practice guide is expected to be a framework for students to have good pedagogic competence. The use of new process-based practice guidelines is support for having good pedagogical competence. Pedagogical competence reflects teacher competence in terms of comprehensive views, collaboration, and contributions to the development of pedagogy for higher education (Reygard, 2010 in Suciu \& Mata, 2011). 
Science teacher competence in science content is the ability of teachers to understand the science concepts and then extend that concept systematic concepts that one can connect with other science concepts (Rahman, 2017). Through the process skills, the concepts obtained by prospective teachers will be more meaningful because students' thinking skills will be more developed (Karsli \& Sahin, 2009). It is inevitable that there is a need for current teachers and prospective teachers to acquire science process skills (Rauf, et al, 2013). Science process skills needed by the students as prospective teachers to have pedagogic competence which is expected to be a time of skills and expertise directly into the field.

Based on the description above, it can be concluded that the development of science process skills at the level of education must continue to be carried out because in reality the field is still found by students and teachers who do not master science process skills. Therefore, it is necessary to conduct research on developing a practical guidebook based on science process skills that can assist students in training and developing student science process skills. The questions raised in this study are:

1. What are the results of the basic physics practicum guide validation I based on science process skills?

2. What are the results of student responses to small group tests on the basic physics practical guidebook I?

3. What are the results of comparative analysis of mastery of science process skills Using the independent sample t-test?

\section{LITERATURE REVIEW}

Basic physics is a fundamental idea that arises from the application of scientific methods that examine the most fundamental ideas about physics needed to study the next level of physics or other sciences (Feynman, Leighton, \& Sands, 1965). The nature of learning physics is certainly not enough to just remember and understand the concepts discovered by scientists. However, what is very important is the habituation of the behavior of scientists in finding concepts carried out through experiments and scientific research. The process of finding concepts that involve fundamental skills through scientific experiments can be carried out and enhanced through practical activities (Kustijono, Jatmiko, \& Ibrahim, 2018). Practicum is a part of teaching that aims to test and execute theories that are learned directly and real by the students themselves (Etkina, 2006).

Practicum will run well and smoothly if it is equipped with a practical guide book (Simbarashe, Emmanuel, \& Masimba, 2016). Gobaw (2016, p. 41), practicum instructions as one of the learning resources in practical activities should be a guide for students in developing science process skills. Therefore, it is important in the basic physics practicum guide to contain aspects of science process skills. Science process skills are special skills that make it easy to learn science, activate students, develop a sense of student responsibility, increase meaningfulness in learning, and teach students about research methods (Karamustafaoğlu, 2011). "These skills are the skills which individuals must have to be scientifically literate. In addition, creative thinking and science process skills are very important for individuals recognizing and solving problems in their daily lives "(AktamıG \& Ergin, In AKA et al, 2010). Process skills describe the types of thinking and reasoning needed. Process skills can be divided into two categories, basic and integrated process skills. In science, basic science process skills help students learn through experience and fundamentals. Students can start with simple ideas, and develop new forms and more complex ideas (Rauf et al, 2013). Ozgelen (2012, p. 283) SPS has been separated into Basic Science Process Skills and Integrated Science Process Skills. Basic SPS consists of observing, using space/time relationships, inferring, measuring, communicating, classifying, and predicting. Integrated SPS includes controlling variables, defining operational, formulating hypotheses, interpreting data, experimenting, formulating models, and presenting the information.

\section{METHODOLOGY OF RESEARCH}

This research is development research that uses the ADDIE development model from Branch (2009). With the development framework as follows:

The analysis phase is the stage where the researcher analyzes the need to develop teaching materials and analyzes the feasibility and development requirements. The stages of analysis conducted by the author include three things, namely needs analysis, curriculum analysis, and student character analysis.

The second stage of the ADDIE model is the design or design phase. At this stage, the basic physics practicum guidebook is based on science process skills that will be developed according to the results of the analysis carried out previously. Furthermore, the design stage is carried out by determining the elements needed in the basic physics practical guidebook based on science process skills such as the preparation of a need map of basic physics practicum guidebooks based on science process skills and a basic physics practical guidebook framework based on science process skills. The researcher also collected references that will be used in developing the material in teaching materials on basic physics practicum guidebooks based on science process skills. At this stage, the researcher also compiled an instrument that would be used to assess basic physics practicum guidebooks based on science process skills developed. 


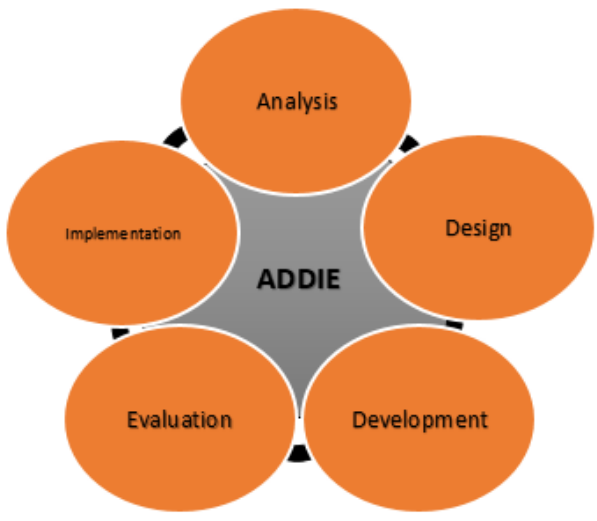

Figure 1: ADDIE development model procedure

The instrument was prepared by taking into account the assessment aspects of the basic physics practicum guidebooks based on science process skills, namely aspects of content feasibility, language feasibility, presentation feasibility, graphic feasibility, and conformity with the approach used. The instrument was compiled in the form of assessment sheets for basic physics practicum guidebooks based on science process skills and response questionnaires. Furthermore, the instruments that have been prepared will be validated to get a valid assessment instrument.

The validation sheet is a content validation sheet and a construct. This validation sheet is given to 2 lecturers as a content and construction expert. The following validation sheet grating contents against basic physics practicum guidebooks based on science process skills.

Table 1: Grid of Content Validation

\begin{tabular}{cl}
\hline Criteria & \multicolumn{1}{c}{ Achievement Indicators } \\
\hline Presentation & Presentation Technique \\
\cline { 2 - 2 } $\begin{array}{c}\text { Feasibility of } \\
\text { Content }\end{array}$ & Supporting the Presentation of Material \\
\cline { 2 - 2 } & Material coverage \\
\cline { 2 - 2 } & Updates \\
\cline { 2 - 2 } & Developing science process skills \\
\hline Language & In accordance with the development of students \\
\cline { 2 - 2 } & Communicative \\
\cline { 2 - 2 } & Dialogic and interactive \\
\cline { 2 - 2 } & Straightforward \\
\cline { 2 - 2 } & Coherence and the demands of the thought line \\
\cline { 2 - 2 } & Use of the term \\
\hline
\end{tabular}

Furthermore, for grating sheet construct validation of the basic physics practicum guidebooks based on science process skills. The following can be seen in Table 2 .

Table 2: Grid of Constructed Validation

\begin{tabular}{lc}
\hline Aspect of Assesment & Indicator \\
\hline Adequacy of guidance contents & Conformity of the guide content \\
\cline { 2 - 2 } & Presentation \\
\hline Accuracy of the Guide Contents & Organization \\
\cline { 2 - 2 } & Format \\
\cline { 2 - 2 } & Consistency \\
\hline Interesting of Guide Contents & The shape and size of the letters \\
\cline { 2 - 2 } & Language \\
\hline & Design guide \\
\hline
\end{tabular}


Then for a questionnaire, the response was given to Physics Education students of Jambi University. The response questionnaire grid can be seen in Table 3 below.

Table 3: Grille Questionnaire Response Product Trial

\begin{tabular}{ll}
\hline \multicolumn{1}{c}{ Aspect } & \multicolumn{1}{c}{ Indicator } \\
\hline Interest & $\begin{array}{l}\text { Interest in the use of practical guides } \\
\text { Basic Physics I }\end{array}$ \\
\cline { 2 - 2 } & The interest contents practical guide \\
\hline Demands & Claims step practicum \\
\hline Easiness & level of difficulty \\
\hline
\end{tabular}

The development stage is the product realization stage. At this stage, the development of a basic physics practicum guidebooks based on science process skills was carried out in accordance with the design. After that, the basic physics practicum guidebooks based on science process skills will be validated by expert lecturers. In the validation process, the validator uses instruments that have been prepared in the previous stage. Validation is done to assess the content and construct validity. The validator was asked to provide an assessment of the basic physics practicum guidebooks based on science process skills developed based on the feasibility aspects of basic physics practicum guidebooks based on science process skills and provide suggestions and comments relating to the contents of the basic physics practicum guidebooks based on science process skills which will later be used as a benchmark for revision of improvement and refinement of basic physics practicum guidebooks based on science process skills. Validation was carried out so that in the end basic physics practicum guidebooks based on science process skills was declared feasible to be implemented in learning activities. At this stage, the researcher also analyzed the data on the results of the assessment of basic physics practicum guidebooks based on science process skills obtained from the validator. This was done to obtain the validity value of the basic physics practicum guidebooks based on science process skills.

The fourth stage is implementation. The implementation was carried out in a small group of 198 students to see students' science process skills using a basic physics practicum guidebooks based on science process skills which were assessed by observation sheet. At this stage, researchers also carried out questionnaires response to students which contained items of statements about the use of basic physics practicum guidebooks based on science process skills in practicum. This is done to obtain data related to the practicality value of using basic physics practicum guidebooks based on science process skills.

At the evaluation stage, researchers conducted a science process skills analysis based on the input obtained from the response questionnaire or field notes on the observation sheet by using descriptive and inferential statistics, namely the t-test assisted by the SPSS 24 computer program. It is intended that the basic physics practicum guidebooks based on science process skills developed is truly appropriate and can be used by a wider university.

\section{RESULTS AND DISCUSSION}

The results of the research conducted by this researcher are modifications to the basic physics practicum guidebooks based on science process skills which contain practical material, work procedures, and lab report formats which are all based on science process skills and use discovery learning models that can train or develop students' science process skills. In this study basic physics practicum guidebooks based on science process skills developed was first modified, then a small group test to see the response of physical education students. then a t-test was conducted to see the differences in the mastery of student science process skills.

\section{a. Validation}

Reconstruction of basic physics practicum guidebooks based on science process skills validation is conducted that analyze the feasibility of practical guidelines to be used. Validity is related to the extent to which an instrument can measure and what will be measured (Tavakoli dan Dennick, 2011). Validation is done in the form of content validation and constructs validation. Content validity is also called logical validity (Newman, et al, 2013). Logical validity contains the word "logical" which means reasoning. So logical validity will see validity based on the results of reasoning (Riyani, et al, 2017). Content validity is used to measure variables of interest such as; content-related validity, intrinsic validity, relevance validity, representative validity, and logical validity or sampling. (Yaghmal, 2003). The more types of estimates of content validity, the greater the trustworthiness of these estimates. The result of the validation of basic physics practices manual 1 based on science process skill by the material expert of phase I can be seen in Table 4 below.

Based on Table 1, content validation on physics construction, basic physics practicum guidebooks based on science process skills got a score of 3.34 with criteria very good and feasible to use. After content validation is complete, the developer guide can proceed to the next validation of the construct validation. The result of the validation of basic physics practicum guidebooks based on science process skills by the construction expert can be seen in Table 5 . 
Table 4: Validation Results of the Contents of the Practicum Guide

\begin{tabular}{lccc}
\hline \multicolumn{1}{c}{ Indicator } & Validation I & Validation II & Validation III \\
\hline Presentation Technique & 2,75 & 3 & 3,5 \\
\hline $\begin{array}{l}\text { Supporting the Presentation } \\
\text { of Material }\end{array}$ & 2,5 & 2,83 & 3,5 \\
\hline Material coverage & 2,67 & 3 & 3,33 \\
\hline Material Accuracy & 3 & 3,25 & 3,25 \\
\hline Updates & 2 & 2 & 3 \\
\hline $\begin{array}{l}\text { Developing science process } \\
\text { skills }\end{array}$ & 3 & 3,25 & 3,5 \\
\hline $\begin{array}{l}\text { In accordance with the } \\
\text { development of students }\end{array}$ & 2 & 2,5 & 3,5 \\
\hline Communicative & 2,5 & 3 & 3 \\
\hline Dialogic and interactive & 2,5 & 2 & 3 \\
\hline Straightforward & 2 & 3 & 3 \\
\hline $\begin{array}{l}\text { Coherence and the demands } \\
\text { of the thought line }\end{array}$ & 2 & 3 & 3,5 \\
\hline Use of the term & 2,33 & 3 & 4 \\
\hline \multicolumn{1}{c}{ Average } & 2,44 & 2,78 & 3,34 \\
\hline \multicolumn{1}{c}{ Category } & Not good & Good & Very good \\
\hline
\end{tabular}

Based on table 1, content validation on physics construction, basic physics practicum guidebooks based on science process skills got a score of 3.34 with criteria very good and feasible to use. After content validation is complete, the developer guide can proceed to the next validation of the construct validation. The result of the validation of basic physics practicum guidebooks based on science process skills by the construction expert can be seen in Table 5 .

Table 5: Results of the Conformation of Constructs of the Practicum Guide

\begin{tabular}{ccc}
\hline Indicator & Score & Category \\
\hline $\begin{array}{c}\text { Conformity of the guide } \\
\text { content }\end{array}$ & 3 & Good \\
\hline Presentation & 3,67 & Very Good \\
\hline Organization & 3 & Good \\
\hline Format & 3,5 & Very Good \\
\hline Consistency & 4 & Very Good \\
\hline $\begin{array}{c}\text { The shape and size of the } \\
\text { letters }\end{array}$ & 3 & Good \\
\hline Language & 3 & Good \\
\hline Design guide & 3 & Good \\
\hline Total & 3,27 & \\
\hline Category & Good & \\
\hline
\end{tabular}

Construct validity refers to the quality of the measuring instrument used whether it has described the construct used as the basis for research. In short, construct validity is an assessment of how well a researcher translates the theory used into a measuring instrument (Nindi, \& Kustijono, 2017). The construct of validity is related to the level of correspondence between the construct and its size (Cronbach and Paul, 1955). In this type of validity, agreements are sought in the form of construction that is 'operationalized', clarifying what we mean when we use this construct (Cohen, et al, 2007). The results of construct validity showed a score of 3.27 with a very good category. After the guide was validated and then tested for physics education students. So based on content validation and construct validation, the physics reconstruction of the basic physics practicum guidebooks based on science process skills can be used for small group trials. The test is done by giving a response questionnaire.

\section{b. Response}

The reconstruction of basic physics practicum guidebooks based on science process skills is done by small group test to see the student's response to the better practicum and is expected to be the framework of students having good pedagogic competence. Questionnaire responses were used to determine students' responses to learning activities using practicum tools (Subamia, et al, 2014). There are several aspects of the expected response including aspects of interest, aspects of the demands and aspects of ease. 


\section{1) Aspect of Interest}

Interest in the product will affect the outlook. The existence of an interest in nature remains in the person who is experiencing it on certain things and the feeling of pleasure towards the field or thing so that someone wants it (Siskawati, et al, 2016). If the product does not attract attention, then the product is considered not good and if the product attracts attention then the product is considered good. Interest in a product will help to shape an opinion on the quality of a product. The more interested in a product than the more consider the product as a good product. Interest will have a positive effect on product use decisions (Marisa, 2013). Table 8 below shows the student's response to the interesting aspect of the reconstruction of the Basic Physics lab guide based on the science process skills.

Table 6: Questionnaire Response Testing Products

\begin{tabular}{lcc}
\multicolumn{1}{c}{ Statement } & Score & Percentage \\
\hline This practical guide is very interesting and not boring & 3,1 & $77,5 \%$ \\
\hline The look of this guide makes me excited to carry out the lab & 3,3 & $82,5 \%$ \\
\hline This practical guide led me to become bored while doing practical & 3 & $75 \%$ \\
\hline I feel depressed and tense during the practicum is by using this practical guide & 3,3 & $82,5 \%$ \\
\hline I feel tired and lazy when using this practical guide in lab activities & 3,6 & $90 \%$ \\
\hline This practicum guide is no different from the usual practicum guide & 3,1 & $77,5 \%$ \\
\hline This practical guide allows me to think deeply & 3,1 & $77,5 \%$ \\
\hline
\end{tabular}

Based on Table 8 each aspect of interest has a percentage score greater than 3 with a percentage of more than $75 \%$, which means the interesting aspect has reached minimum criteria with good category (Widoyoko, 2014).

\section{2) Aspects of Demands}

Demands are the composition of the presentation of teaching materials. The orderly arrangement makes students easy to learn and also guides students to get used to thinking coherently (Muyanto, 2010). Table 9 below shows the student's response to the interesting aspect of the reconstruction of the Basic Physics lab guide based on science process skills.

Table 7: Result of questionnaire response on the aspect of demands

\begin{tabular}{lcc}
\hline \multicolumn{1}{c}{ Statement } & Score & Percentage \\
\hline $\begin{array}{l}\text { In every activity, I could write a hypothesis consistent with the } \\
\text { objectives of the practicum }\end{array}$ & 3,2 & $80 \%$ \\
\hline $\begin{array}{l}\text { The order of presentation in this guide easier for me in doing } \\
\text { practical }\end{array}$ & 3 & $75 \%$ \\
\hline
\end{tabular}

Based on table 9 each aspect of the demands has a score of 3 with a percentage of more than $75 \%$, the result can be said that aspects of the demands have reached the criteria with a good category.

\section{3) Aspects of Convenience}

The use of instructional guidance relates to how easily or not the book is used by the reader. If the components of the guides are difficult to learn, the user of the instructional guide tends to discourage learning the guides (Faradila and Soesanto, 2013). Table 10 below shows the student's response to the convenience aspects of reconstruction of the Basic Physics lab guide I based on science process skills.

Based on the table each aspect of the average ease has a big score of 3 with a percentage of more than $75 \%$, although there is 1 aspect of ease that has a score of less than 3, but these results are also categorized either (Widoyoko, 2014), so from the results can be said that the aspect of ease has reached the criteria with good category.

\section{c. Results of Hypothesis Testing Analysis}

Hypothesis testing carried out in this study was to use the independent sample t-test. The results of a comparative analysis of mastery of science process skills (SPS) using the independent sample t-test test in the Physics Education Study Program are shown in table 9.

Testing the hypothesis in this study is seen from comparing the values obtained $t_{\text {count }}$ with the value of $t_{\text {table. }}$. The value of $t_{\text {table }}$ can be found in the statistical table at the significance of 0.025 (2-sided test) with the degree of freedom (df) 196. In this study, the results for $t_{\text {table }}$ are 1.65259. Whereas for the value of $t_{\text {count }}$ can be seen in Table 9 (column $t$ ) which is 27,224. The hypothesis testing criteria are the value of $\mathrm{t}_{\text {count }}$ is greater than the value of $\mathrm{t}_{\text {table }}$, there is a rejection of $\mathrm{H}_{0}$ (Argyrous, 2011). 
Table 8: Response questionnaire results on the convenience aspect

\begin{tabular}{lcc}
\multicolumn{1}{c}{ Statement } & Score & Percentage \\
\hline $\begin{array}{l}\text { This lab guide makes it easier for me to understand Basic Physics I } \\
\text { materials }\end{array}$ & 3 & $75 \%$ \\
\hline This lab guide makes me confused in doing lab work & 3 & $75 \%$ \\
\hline Using this practical guide I find it difficult to understand the subject matter & 3,1 & $77,5 \%$ \\
\hline This lab guide adds my insights into Physics study & 3,3 & $82,5 \%$ \\
\hline $\begin{array}{l}\text { The method or method used in this practical guide makes it easy for me to } \\
\text { understand the concepts of Basic Physics materials I }\end{array}$ & 3 & $75 \%$ \\
\hline $\begin{array}{l}\text { With this practicum guide, I find it easier to remember physics concepts } \\
\text { that have been studied }\end{array}$ & 3 & $75 \%$ \\
\hline Activity steps in the practice guide make it easier for me to get data. & 2,9 & $72,5 \%$ \\
\hline Using this guide, I can design an experiment & 3,2 & $80 \%$ \\
\hline $\begin{array}{l}\text { Preliminary questions on practicum practitioners make it easy for me to do } \\
\text { the lab work }\end{array}$ & 3 & $75 \%$ \\
\hline $\begin{array}{l}\text { The final question on this lab workshop made it easier for me to make a } \\
\text { conclusion }\end{array}$ & 3,1 & $77,5 \%$ \\
\hline
\end{tabular}

Table 9: Results of comparative analysis of mastery of science process skills

Using the independent sample t-test

\begin{tabular}{ccc}
\hline \multicolumn{3}{c}{ Independent Sample T-test } \\
\hline & $\mathrm{t}$ & $\mathrm{Df}$ \\
& & \\
\hline \multirow{2}{*}{$\begin{array}{c}\text { Science Process } \\
\text { Skills }\end{array}$} & 27,224 & 196 \\
\cline { 2 - 3 } & 27,224 & 194.832 \\
\hline
\end{tabular}

This means that there is a significant difference in the mastery of Science Process Skills (SPS) between physics education students who use basic physics practicum guidebooks based on science process skills and students who do not use basic physics practicum guidebooks based on science process skills.

Table 10: Statistical groups results of comparative analysis of mastery

Of science process skills using the independent sample t-test

\begin{tabular}{lcc}
\hline \multicolumn{1}{c}{ Mahasiswa } & \multicolumn{2}{c}{ Science Process Skills } \\
\cline { 2 - 3 } & Mean & Std. Deviation \\
\hline $\begin{array}{l}\text { Using practicum } \\
\text { guide based Science }\end{array}$ & 3,2366 &, 29059 \\
Process Skills & &, 31402 \\
\hline $\begin{array}{l}\text { Not using practicum } \\
\text { guide based Science }\end{array}$ & 2,0660 & \\
Process Skills & & \\
\hline
\end{tabular}

Based on Table 10, it can be seen that the average value of science process skills of students who use basic physics practicum guidebooks based on science process skills is 3.2366. While the average value of science process skills of students who do not use basic physics practicum guidebooks based on science process skills is 2.0660 . This shows that the use of basic physics practicum guidebooks based on science process skills can develop and practice students' science process skills. Science process skills are skills that must be possessed by physics education students as a prospective teacher because science process skills involve physical and mental activities to acquire and master science. Kim (2007) Science Process Skills (SPS) can help students in training the development of students' mental processes in making decisions. Miles (2010). In addition, science processes have competencies that can be obtained from knowledge and understanding.

Based on the findings in this study, it can be seen that the use of practical guidance based on science process skills using the discovery learning model helps students practice science process skills. presenting the initial questions about the practiced material directs experimental class students to various activities such as observing, predicting, interpreting, applying concepts, 
planning experiments and communicating the results also requiring students to have prior knowledge so that when doing practicum, students already understand what must be done both to determine the tools and materials to be used as well as how to design experiments to get the desired data. This is in accordance with the opinion of Tafa (2012) that it is very important for students/students to have the initial knowledge before conducting practicum activities because this will help assist them in participating in the lab learning process.

The aspect of the book's demands is the message conveyed through discourses, texts, images from one chapter to another adjacent chapter and the inner bib in the chapter reflects a logical relationship. The demands can be measured by the logical relations that occur between paragraphs and between adjacent sentences (BSNP, 2014). On the other hand, the assessment of the demands and integrity of paragraphs is seen from the delivery of messages through discourse, text, images, illustrations between adjacent paragraphs and intercostals in paragraphs reflecting logical relationships. Aspects of demands make it easier for students to use practical guides. Based on questionnaire response got an average score of 3.1 with a good category. This is because the basic physics practicum guidebooks based on science process skills of the reconstructed process, the presentation steps such as starting from the objectives, the preliminary task, there are stimuli or problems, problem identification, data collection, data processing, conclusion making students easy to use when practice.

The aspect of a product's interest shows how one likes a product (Arriestina, 2015). Student interest can be seen from how much interest of students in using the product (Kurniahayati and Syamsurizal, 2012). Based on the response questionnaire given, the students response to the reconstruction of basic physics practicum guidebooks based on science process skills obtained an average score of 3.21 with a good category. This is because students are interested in the reconstruction of the practicum guidance provided so that it raises interest in practicum using the reconstructed practicum guide. With a basic physics practicum guidebooks based on science process skills, the students become more active because they have to learn first before practicing to understand the material to be practiced.

Of course, by using the reconstruction of basic physics practicum guidebooks based on science process skills of this student can have good skills so as to have experience as a prospective teacher so that later can teach it to students in science class. One's professional knowledge, which is informed by one's professional background, experience, perceptions can be seen from the teachers' behaviors (Rauf, et al, 2013). Having adequate understanding and process science skills are considered an important aspect of science learning (Kruea-In and Thongperm, 2014). As prospective teachers, who will be responsible for preparing educational activities related to SPS in the future, so required to be educated in such a way that they have SPS (Farsakoğlu, 2012).

\section{CONCLUSIONS}

From this research can be produced a basic physics practicum guidebooks based on science process skills. Based on the validation results indicate that the reconstruction of basic physics practicum guidebooks based on science process skills that got good category result so that it can be used. The results of student responses when using the reconstruction basic physics practicum guidebooks based on science process skills are well categorized so as to improve students' science process skills.

\section{REFERENCES}

1. Aka, Elvan Ġnce ., Ezgi Güven, Mustafa Aydoğdu. (2010). Effect of Problem Solving Method on Science Process Skills and Academic Achievement. Turkish Science Education. 7(4). 13-25

2. Argyrous, G. (2011). Statistics for Research: With a Guide to SPSS. Australia: Sage Publication. 1-397

3. Arriestina, N. A., \& Nor, M. N. (2015). Attitudes toward Student Science in the Application of Guided Inquiry Learning. Student Online Journal (JOM) Field of Teaching and Education, 2(1), 1-11.

4. BSNP. (2014). Instrument Rating Textbook Lesson 2014. BSNP-indonesia.org /?p=1340 (accessed on 09 March 2018, at 15:30)

5. Cansiz, Mustafa, Semra Siregar dan Ceren Oztekin. (2016). Exploring The Development Of Science Process Skills Through History Of Science Instruction. Strand 16, Science in the primary school, 735-736.

6. Cohen, L., Manion, L., \& Morrison, K. (2007). Research methods in education. Routledge. https://doi.org/10.4324/9780203029053

7. Cronbach, L. J., \& Meehl, P. E. (1955). Construct validity in psychological tests. Psychological Bulletin, 52(4), 281. Doi: http://dx.doi.org/10.1037/h0040957

8. Effiong, O. E., \& Igiri, C. E. (2015). Impact of Instructional Materials in Teaching and Learning of Biology in Senior Secondary Schools in Yakurr LG A. International Letters of Social and Humanistic Sciences, 62, 27-33. Retrieved April 21, 2019, from https://www.learntechlib.org/p/176668/.

9. Etiubon, R. U., \& Udoh, N. M. (2017). Effects of Practical Activities and Manual on Science Students' Academic Performance on Solubility in Uruan Local Education Authority of Akwa Ibom State. Journal of Education and Practice, 8(3), 202-209. Retrieved http://iiste.org/Journals/index.php/JEP. 
10. Etkina, E., Van Heuvelen, A., White-Brahmia, S., Brookes, D. T., Gentile, M., Murthy, S., ... \& Warren, A. (2006). Scientific abilities and their assessment. Physical Review special topics-physics education research, 2(2), 1-15. https://doi.org/10.1103/PhysRevSTPER.2.020103

11. Fajriani. (2017). Development of Chemical Basic Practicum Module Integrated Physics Sciences Student Department of Physics Education. Thesis UIN Alauddin Makassar

12. Faradila, R. S. N., \& Soesanto, H. (2016). Analysis of Effect of Perception of Ease of Use and Perception of Benefits to Buy Interest with Confidence as Intervening Variable (Study on Visitors Online Shop berrybenka.com in Students of Diponegoro University). Diponegoro Journal of Management, 5(3), 239-250.

13. Farsakoğlu, Ö. F., Şahin, Ç., \& Karsli, F. (2012, June). Comparing science process skills of prospective science teachers: A cross-sectional study. In Asia-Pacific Forum on Science Learning and Teaching (Vol. 13, No. 1, pp. 1-21). The Education University of Hong Kong, Department of Science and Environmental Studies.

14. Feynman, R. P., Leighton, R. B., \& Sands, M. (1965). The Feynman lectures on physics; vol. i. American Journal of Physics, 33(9), 750-752. https://doi.org/10.1119/1.1972241

15. Feyzýoglu, B. (2009). An investigation of the relationship between science process skills with efficient laboratory use and science achievement in chemistry education. Journal of Turkish Science Education, 6(3), 114-132.

16. GBG 005. (2005). SCIENCE GRADE 5 From Integrated Resource Package 2005. British Columbia: Ministry of Education. 10.

17. Gobaw, G. F., \& Atagana, H. I. (2016). Assessing Laboratory Skills Performance in Undergraduate Biology Students. Academic Journal of Interdisciplinary Studies, 5(3), 113. https://doi.org/10.5901/ajis.2016.v5n3p113

18. Karamustafaoglu, Sevilay. (2011). Improving the Science Process Skills Ability of Science Student Teachers Using I Diagrams. Eurasian J. Phys. Chem. Educ, 3(1), 26-38

19. Karsli, F., \& Sahin, Ç. (2009). Developing worksheet based on science process skills: Factors affecting solubility. In Asia-Pacific Forum on Science Learning \& Teaching 10 (1), 1-12. https://doi.org/10.1016/j.sbspro.2009.01.158

20. Kruea-In, N., \& Thongperm, O. (2014). The teaching of science process skills in the contexts: Status, supports, and obstacles. Procedia-Social and Behavioral Sciences, 141, 1324-1329. https://doi.org/10.1016/j.sbspro.2014.05.228

21. Kustijono, R., Jatmiko, B., \& Ibrahim, M. (2018). The Effect Of Scientific Attitudes Toward Science Process Skills In Basic Physics Practicum By Using Peer Model. International Journal Of Geomate, 15(50), 82-87. https://doi.org/10.21660/2018.50.IJCST50

22. Kuswanto, 2017. Profile Capability Early New Student Science Process Skills Physical Education Academic Year 2016/2017 In Doing Practical Physics I at Jambi University: Thesis, Department of Mathematics and Natural Sciences, FKIP University of Jambi. 1-85.

23. Lestari, U. (2017). Description Science Process Skills of Physics Education Students of Jambi University at Basic Physics Practicum Activity I (Science Process Skills: Observation, Prediction, Classification and Conclusion). Thesis, Department of Mathematics and Natural Sciences Education, FKIP University of Jambi. 1-10.

24. Newman, I., Lim, J., \& Pineda, F. (2013). Content validity using a mixed methods approach: Its application and development through the use of a table of specifications methodology. Journal of Mixed Methods Research, 7(3), 243260. https://doi.org/10.1177/1558689813476922

25. Nindy Apsari, A., \& Kustijono, R (2017). Development Of E-Book Using Kvisoft Flipbook Maker To Train Science Process Skill For Senior High School Students In Curriculum 2013. Inovasi Pendidikan Fisika, 6(3), 285-291

26. Normayanti. (2017). Description Science Process Skills of Physics Education Students of Jambi University on Basic Physics Practicum Activities I (SPS: Defining Variables Operationally, Measuring, Obtaining and Processing Data, and Creating Data Tables), Department of Physics Education, FKIP Jambi University. 1-101.

27. Octaviandari, Arniza Resti. (2016). Module Development Physics Science Process Skills Based On Optical Materials Tools For Junior Class Students VIII. Thesis. State Islamic University Sunan Kalijaga. Yogyakarta. 1-245.

28. Özgelen, S. (2012). Students' science process skills within a cognitive domain framework. Eurasia Journal of Mathematics, Science \& Technology Education, 8(4), 283-292

29. Rahman, M. H. (2014). Professional Competence, Pedagogical Competence and the Performance of Junior High School of Science Teachers. Journal of Education and Practice, 5(9), 75-80.

30. Rauf, R. A. A., Rasul, M. S., Mansor, A. N., Othman, Z., \& Lyndon, N. (2013). Inculcation of science process skills in a science classroom. Asian Social Science, 9(8), 47-57. https://doi.org/10.5539/ass.v9n8p47

31. Rezba, R J, Constance. SS, Ronald. F, James. F, James. O, Harold. H J,. (1995). Learning and Assesing science process skills. Kndall: Hunt publishing company, 1-269.

32. Riyani, R., Maizora, S., \& Hanifah, H. (2017). Validity Test Development Test For Measuring Relational Understanding Ability To Square Quality Learning Students Class Viii Smp. Jp2ms, 1(1). 2017. https://doi.org/10.33369/jp2ms.1.1.60-65

33. Sheeba, M. N. (2013). An Anatomy of Science Process Skills in The Light of the Challenges to Realize Science Instruction Leading to Global Excellent in Education. Education Confab, 2(14), 108-123. 
34. Simbarashe, M., Emmanuel, C., \& Masimba, M. (2016). A Study for Teaching Advanced Level Physics Practical and Solution approach to Practical Questions. Journal of Innovative Research in Education, 1(1), 36-48.

35. Siskawati, M., Pargito, P., \& Pujiati, P. (2016). Development of Monopolistic Learning Media to Improve Student Geography Learning Interest. Journal of Social Studies, 4(1): 72-80.

36. Subamia, I. D. P., Wahyuni, I. G. A. N. S., \& Widiasih, N. N. 2014. Development of IPA Practicum Supporting Tool in Environmental Based SMP. Journal of Education and Teaching, 47(1): 29-39.

37. Suciu, A. I., \& Mâtâ, L. (2011). Pedagogical Competences - The Key To Efficient Education. International Online Journal of Educational Sciences, 3(2), 411-423.

38. Tavakol, Mohsen dan Reg Dennick. 2011. Making sense of Cronbach's alpha. International Journal of Medical Education. 2, 53-55. https://doi.org/10.5116/ijme.4dfb.8dfd

39. Widoyoko, Eko Putro. (2014). Technique of Preparation of Research Instrument. Yogyakarta: Pustaka Pelajar, 1-251

40. Yaghmale, F. (2003). Content validity and its estimation. Journal of Medical Education, 3(1), 25-27

41. Zeidan, A. H., \& Jayosi, M. R. (2014). Science process skills and attitudes toward science among palestinian secondary school students. World Journal of Education, 5(1), 13. https://doi.org/10.5430/wje.v5n1p13 